\title{
Processing of Total Chromium and Organic Compound in Tannery Wastewater Using Eggshell and Zeolite Sand
}

\author{
Soni Setiadji ${ }^{1}$, Citra Fitriani Kusman ${ }^{2}$, Masfufah Mulyasyaroh ${ }^{3}$, Yusuf Amin ${ }^{4}$, Vina \\ Amalia $^{5}$, Eko Prabowo Hadisantoso ${ }^{6}$, Yusuf Rohmatulloh ${ }^{7}$, Tsani Adiyanti ${ }^{8}$ \\ \{s.setiadji@uinsgd.ac.id ${ }^{1}$,ntafitri@gmail.com², masfufahmulyasyaroh@yahoo.com ${ }^{3}$, \\ yusufaminsetiawan@gmail.com ${ }^{4}$, vinaamalia@uinsgd.ac.id ${ }^{5}$, ekopra05@gmail.com6 ${ }^{6}$, \\ dyusuf.rohmat@gmail.com ${ }^{7}$, tsani.adiyanti05@gmail.com ${ }^{8}$ \} \\ Department of Chemistry, Faculty of Science and Technology, UIN Sunan Gunung Djati \\ Bandung, Jl. A.H. Nasution No.105 Bandung, West Java, 40614, Indonesia ${ }^{1,2,3,4,5,6,7,8}$.
}

\begin{abstract}
Tannery industry was generating wastewater from its production activities. This wastewater contains chromium metal ions as a hazardous and toxic compound for human health. In this study, treating of chromium metal ions and organic compounds in the tannery wastewater has been studied. The wastewater processing was used by a combination of precipitation and adsorption methods. Precipitation uses $\mathrm{Ca}(\mathrm{OH})_{2}$ as a natural coagulant that obtained from chicken eggshell after calcined at high temperature. Adsorption process uses zeolite sand that activated with $\mathrm{BaCl}_{2}$. Precipitation performed at $\mathrm{pH} 11$, then followed with adsorption optimized through variation of adsorbent weight and contact time. From the results shows that optimum condition due to the combination of precipitation and adsorption was occurred at $\mathrm{pH} 11$, adsorbent weight $0.5 \mathrm{~g}$ and contact time 30 minutes where the methods can reducing total chromium ions and organic compounds up to $99 \%$ as elimination level. The content of the wastewater sample after processing reducing total chromium up to $0.043 \mathrm{mg} / 1, \mathrm{BOD}_{5}$ up to 2.56 $\mathrm{mg} / \mathrm{l}$, COD up to $4.3504 \mathrm{mg} / \mathrm{l}$ and TSS up to $3.00 \mathrm{mg} / \mathrm{l}$. The results explain that the wastewater pollutant referenced the standard quality of tannery industry activities have been fulfilled, so that secure to dispose into the environment.
\end{abstract}

Keywords: Tannery Wastewater, Chromium Ions, Precipitation, Chicken Eggshell, Natural Zeolite.

\section{Introduction}

Increased industry development can cause problems because waste produced by the industry can pollute the environment. The leather tanning industry is one of the industries in Indonesia that produces hazardous and toxic substances (B3), i.e, the presence of chromium metal from the tannery industry is toxic. According to Decree of Environment State Minister No. 51/MENLH/10/1995 that concerning wastewater quality standards for industry activities, the maximum limit of total chromium $(\mathrm{Cr})$ allowed to be disposed into the environment is 0.6 $\mathrm{mg} / \mathrm{l}[1]$.

This study was processing to chromium metal ions from wastewater of leather tanning industry in Sukaregang, Garut. This study was focused on processing the content of 
chromium, $\left(\mathrm{Cr}^{3+}\right)$ and $\left(\mathrm{Cr}^{6+}\right)$ were mainly found in tannery wastewater [1]. In this study was carried out through a combination process of precipitation and adsorption, so that the processed wastewater is safe to dispose directly into the effluent in the surrounding community.

The batch method is a simple method where it was chosen for this experiment. The batch system is a simple experiment for processing the chromium metal in tannery wastewater using precipitate and adsorbent. While waste sampling carried out through the grab sample method.

Processing of tannery wastewater was carried out through two stages, i.e. precipitation and adsorption. The precipitation of chromium metal ions was carried out by adding strong alkaline into the wastewater sample, thereby changing the physical condition of wastewater from dissolved form to suspended solid [1]. $\mathrm{Ca}(\mathrm{OH})_{2}$ (hydrated $\mathrm{CaO}$ ) used as an alkaline that prepared by the calcination of chicken eggshell at high temperatures [2]. This $\mathrm{Ca}(\mathrm{OH})_{2}$ has a high alkaline strength where it is environmentally friendly and it can be made from inexpensive sources. The second stage is absorption to process the other pollutants in wastewater where this is done after the precipitation stage. The adsorption process of wastewater uses commercial zeolite sand [3] that activated by $\mathrm{BaCl}_{2}$ to improve its adsorption properties. The adsorption process can use natural zeolite and synthetic zeolite. Almost all types of synthetic zeolite can be used as adsorbents [4]. But the synthetic zeolite is made through methods that are not simple and require pure material [5]-[7]. So that commercial zeolite sand is one of alternative as cheap adsorbents. In addition, measurements of other pollutant were also conducted such as $\mathrm{BOD}_{5}, \mathrm{COD}, \mathrm{TSS}$, sulfide and $\mathrm{pH}$.

\section{Methodology}

Chemicals used in this research are $\mathrm{BaCl}_{2} .2 \mathrm{H}_{2} \mathrm{O}$ (Merck), $\mathrm{H}_{2} \mathrm{SO}_{4}$ (Merck), $\mathrm{K}_{2} \mathrm{CrO}_{4}$ (Merck), commercial zeolite sand from pet shop, chicken eggshell waste and Aqua DM. Wastewater samples were taken at one sampling point from one of leather tanning industries located in Sukaregang Garut.

\subsection{Preparation of Eggshell $\mathrm{CaO}$ and Activated Zeolite Sand}

Chicken eggshell was cleaned, dried, smoothed and sieved that resulted powder with 149 microns size. Then it calcined at a temperature $700{ }^{\circ} \mathrm{C}$ for 4 hours to get $\mathrm{CaO}$ powder. This powder characterized using XRD (X-Ray Diffraction). Zeolite sand was smoothed and sieved become powder with 149 micron size. Then it soaked with a solution of $2 \mathrm{mg} / 1 \mathrm{BaCl}_{2} \cdot 2 \mathrm{H}_{2} \mathrm{O}$, stirred, let stand for 24 hours. The obtained precipitate is washed with distilled water. The activated zeolite sand was dried and characterized by FTIR (Fourier Transform Infrared).

\subsection{Precipitation Process}

Each tannery wastewater sample $50 \mathrm{ml}$ was mixed $10 \% \mathrm{w} / \mathrm{v} \mathrm{Ca}(\mathrm{OH})_{2}$ in aqua $\mathrm{DM}$ until $\mathrm{pH} 8,9,10,11$ and 12 . Then all samples stirred for 30 minutes and let stand for 24 hours thus we determine the optimum $\mathrm{pH}$ of precipitation process and then all samples was measured with AAS (Atomic Absorption Spectrometer). Next the filtered supernatant at optimum $\mathrm{pH}$ will be used as samples to adsorption process stage. 


\subsection{Adsorption Process}

Resulted wastewater samples of precipitation were added with activated zeolite sand, stirred, and centrifuged then taken the waste water sample. In this adsorption process, variations in weight of adsorbent i.e. $0.5,1.5$ and $2.5 \mathrm{~g}$ and variations of contact time i.e. 0.5, 2, 3.5 and 5.5 hours were carried out. Wastewater samples from adsorption at this optimum condition were tested for wastewater quality, i.e. Biological Oxygen Demand (BOD), Chemical Oxygen Demand (COD), Total Suspended Solid (TSS), sulfide, pH and total chromium ions. AAS (Atomic Absorption Spectrometer) are used to measure the total chromium ions for all samples. Then it compared with the initial wastewater sample that resulted from the same measurement. Calculation of elimination efficiency of pollutant parameter is formulated as $\mathrm{E}(\%)=[(\mathrm{Co}-\mathrm{C}) / \mathrm{Co}] \times 100 \%$, with $\mathrm{Co}$ and $\mathrm{C}$ are the initial and final (after processing) of concentrations samples, respectively.

\section{Results and Discussion}

\subsection{Precipitation Using Eggshells CaO}

Chicken eggshell is a source of $\mathrm{CaCO}_{3}$ which it will decompose become $\mathrm{CaO}$ through the calcination process at high temperatures $\left(\mathrm{T}>450{ }^{\circ} \mathrm{C}\right)[8] . \mathrm{CaO}$ is a natural coagulant that it is used to precipitates chromium metal ions in wastewater. Alkaline characteristic of $\mathrm{CaO}$ and $\mathrm{Ca}(\mathrm{OH})_{2}$ are more high than $\mathrm{CaCO}_{3}$. Therefore, Eggshell was calcined at temperature $700{ }^{\circ} \mathrm{C}$ intended so $\mathrm{CaCO}_{3}$ can decompose become $\mathrm{CaO}$ had better.

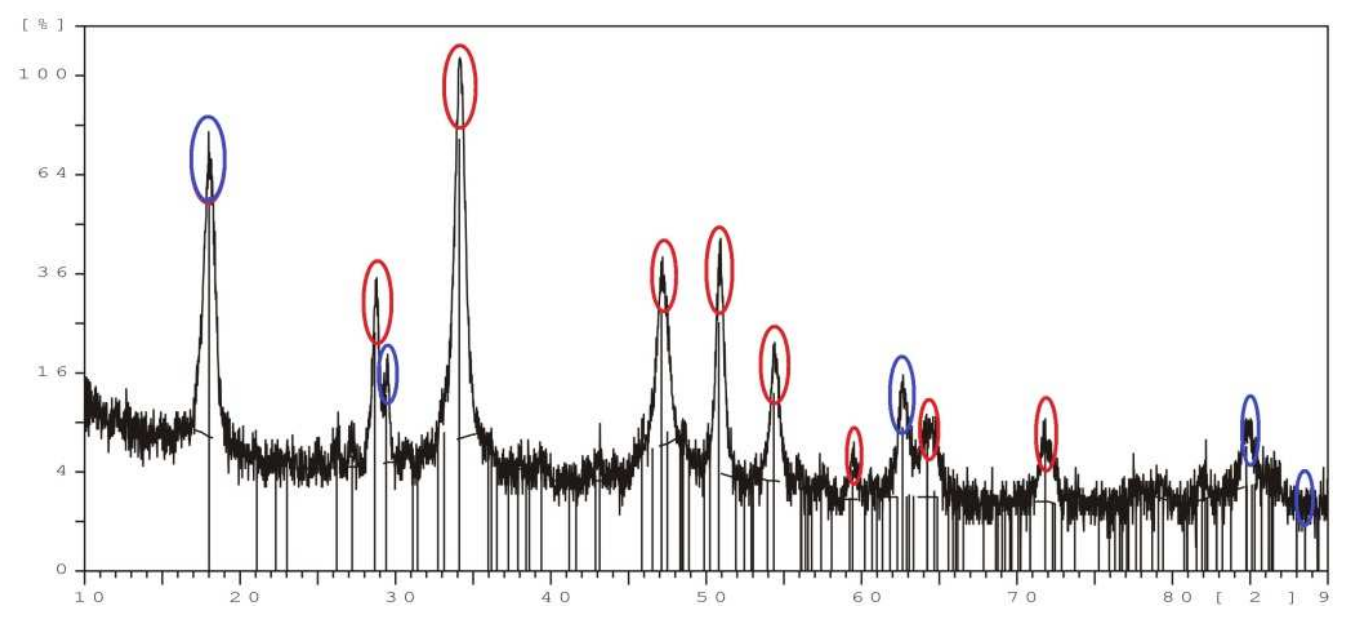

Figure 1. XRD pattern of calcined chicken eggshell at $700^{\circ} \mathrm{C}\left[\mathrm{red}\right.$ circles $\left(\mathrm{Ca}(\mathrm{OH})_{2}\right.$, blue circles $\left.\left(\mathrm{CaCO}_{3}\right)\right]$.

The results of XRD characterization of calcined chicken egg shells are given in Figure 1, showing the presence of $\mathrm{Ca}(\mathrm{OH})_{2}$ at $2 \Theta=28.6^{\circ} ; 34.1^{\circ}, 47.1^{\circ}, 50.8^{\circ}, 54.3^{\circ}, 59.4^{\circ}, 64.3^{\circ}, 71.8^{\circ}$. $\mathrm{CaCO}_{3}$ was found at $2 \mathrm{\Theta}=18^{\circ}, 29.4^{\circ}, 62.5^{\circ}, 85^{\circ}, 88.5^{\circ}[8]$. 
Pollutants in wastewater can precipitated at alkaline conditions, i.e. increasing the initial $\mathrm{pH}$ of wastewater from acidic $(\mathrm{pH} 4.6)$ to alkaline $(\mathrm{pH}=8,9,10,11$, and 12) by adding a $\mathrm{Ca}(\mathrm{OH})_{2}$ suspension was slightly. Chromium metal contained in wastewater is $2,646.5 \mathrm{mg} / \mathrm{L}$ after 500 times of dilution process, so the chromium content in tannery wastewater is very large. $2.8 \mathrm{ml}$ of $\mathrm{Ca}(\mathrm{OH})_{2}$ suspension was needed to yield $\mathrm{pH} 8,3.95 \mathrm{ml}$ to yield $\mathrm{pH} 9,8.25 \mathrm{ml}$ to yield $\mathrm{pH} 10,9.75 \mathrm{ml}$ to yield $\mathrm{pH} 11$ and $27 \mathrm{ml}$ to yield $\mathrm{pH} 12$. From AAS measurement was resulted that the highest percent of total chromium ions elimination was obtained at $\mathrm{pH} 11$ that shown at Figure 2. Total chromium ions was eliminated from initial concentration 2,646.5 $\mathrm{mg} / \mathrm{l}$ to final concentration $0.185 \mathrm{mg} / \mathrm{l}$ that correlated to activity of $\mathrm{OH}$ ions from coagulant. This precipitation process deposits $\mathrm{Cr}^{3+}$ ions become $\mathrm{Cr}(\mathrm{OH})_{3}$ through reaction $2 \mathrm{Cr}^{3+}{ }_{(\mathrm{aq})}+$ $3 \mathrm{Ca}(\mathrm{OH})_{2(\mathrm{aq})} \rightarrow 2 \mathrm{Cr}(\mathrm{OH})_{3(\mathrm{~s})}+3 \mathrm{Ca}^{2+}{ }_{(\mathrm{aq})}$. Moreover the stirring can increasing the deposition process.

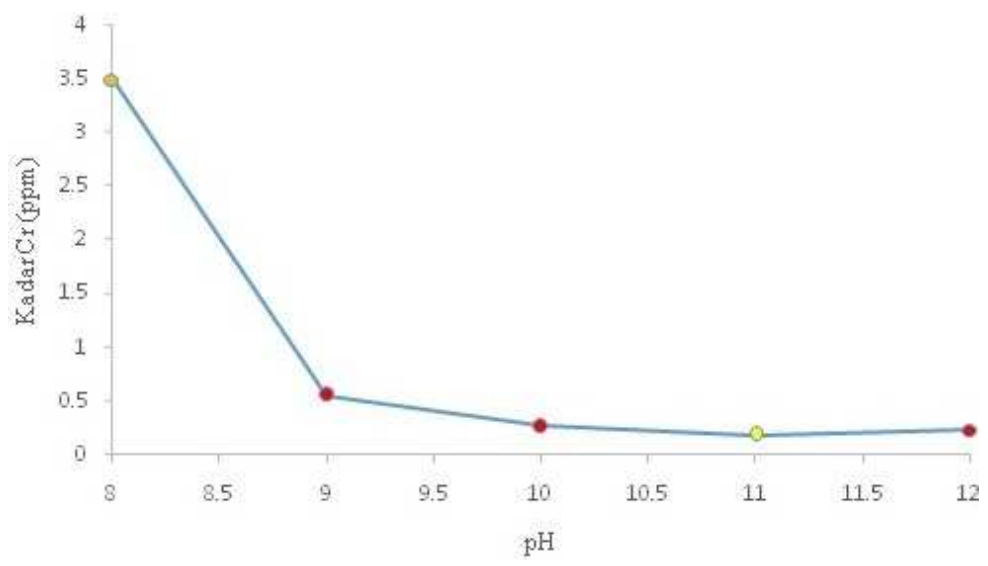

Figure 2. Elimination total chromium ions after the precipitation at various $\mathrm{pH}$.

Beside $\mathrm{Cr}(\mathrm{OH})_{3}$ deposits was formed in wastewater, the precipitation process was change discoloration and odor of wastewater where previously pitch black and bad smell to be clear and odorless. It can be presumed that chromium metal ions, dyes and organic compounds contained in the wastewater almost entirely was settled. Changes of wastewater before and after the precipitation process can be seen in Figure 3 .

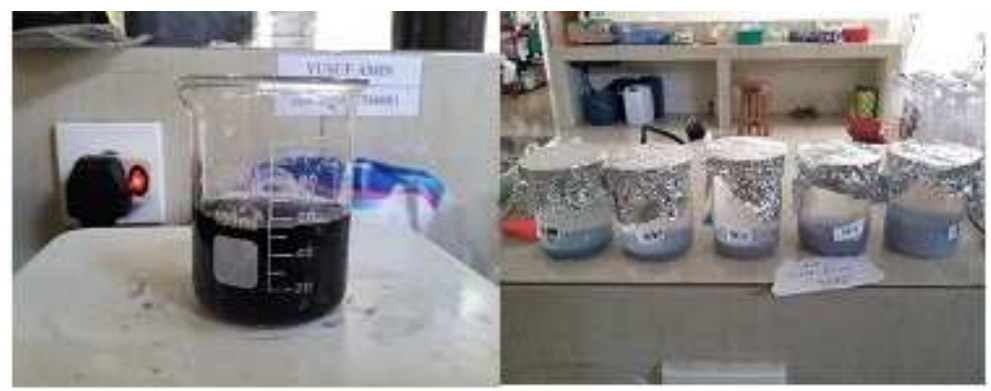

Figure 3. Tannery wastewater from an industry in Sukaregang Garut, after the precipitation (left) and before the precipitation (right). 


\subsection{Adsorption Using Activated Zeolite Sand}

The adsorption process is purposed to optimize the removal of all contaminants in wastewater that has not been lost after the precipitation process. Zeolite sand is a commercial product that easily available. According to improving the adsorption of zeolite sand then it is smoothed as powder of 149 microns size to adding the contact area on surface of the zeolite. After that zeolite powder is immersed in $\mathrm{BaCl}_{2}$ solution to eliminate impurity cations in the zeolite cavity so that the surface of the zeolite becomes active.

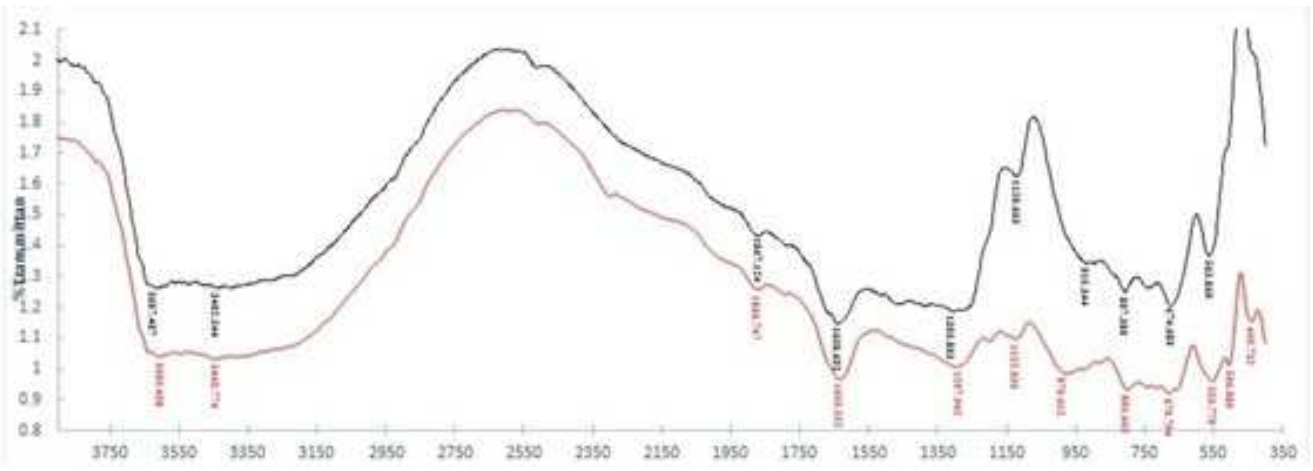

Figure 4. Spectra Infrared of activated zeolite sand (red curve) and zeolite sand (black curve).

The typical absorption of zeolite lies in the wavelength $400-1500 \mathrm{~cm}^{-1}$ which characterizes zeolite skeletal structure. In this study, infrared spectra of zeolite sand at Figure 4. show absorption at $674.689 \mathrm{~cm}^{-1}$ and $679.794 \mathrm{~cm}^{-1}$ that characterize the vibrations of Al-O bonds, absorption at $807.380 \mathrm{~cm}^{-1}$ and $801.662 \mathrm{~cm}^{-1}$ that characterize the vibrations of Si-O-Si bonds, absorption at $915.344 \mathrm{~cm}^{-1}$ and $979.612 \mathrm{~cm}^{-1}$ that characterize vibrations of Si-O-Al bonds [9], absorption at $1,120.663 \mathrm{~cm}^{-1}$ and $1,122.036 \mathrm{~cm}^{-1}$ that characterizes the vibrations of Si-O-Al bonds [9], absorption at $1,638.692 \mathrm{~cm}^{-1}$ and $1,633.252 \mathrm{~cm}^{-1}$ that characterizes vibrations of $\mathrm{O}-\mathrm{H}$ bonds and absorption at $3,607.407 \mathrm{~cm}^{-1}$ and $3,605.458 \mathrm{~cm}^{-1}$ that characterize vibrations of $\mathrm{O}-\mathrm{H}$ bonds [9]. From the infrared spectra, it was predicted that the commercial zeolite sand obtained from pet shop is a natural zeolite but the zeolite type had not been identified. The presence of metal cations in zeolite cavities are characterized as absorption at wavelength smaller than $600 \mathrm{~cm}^{-1}$. This case can predict ion exchange of $\mathrm{Ba}^{2+}$ into zeolite cavity is possible been occurred which accordance to presence of vibrations at $569,444 \mathrm{~cm}^{-1}$ and strengthening of absorption intensity. 


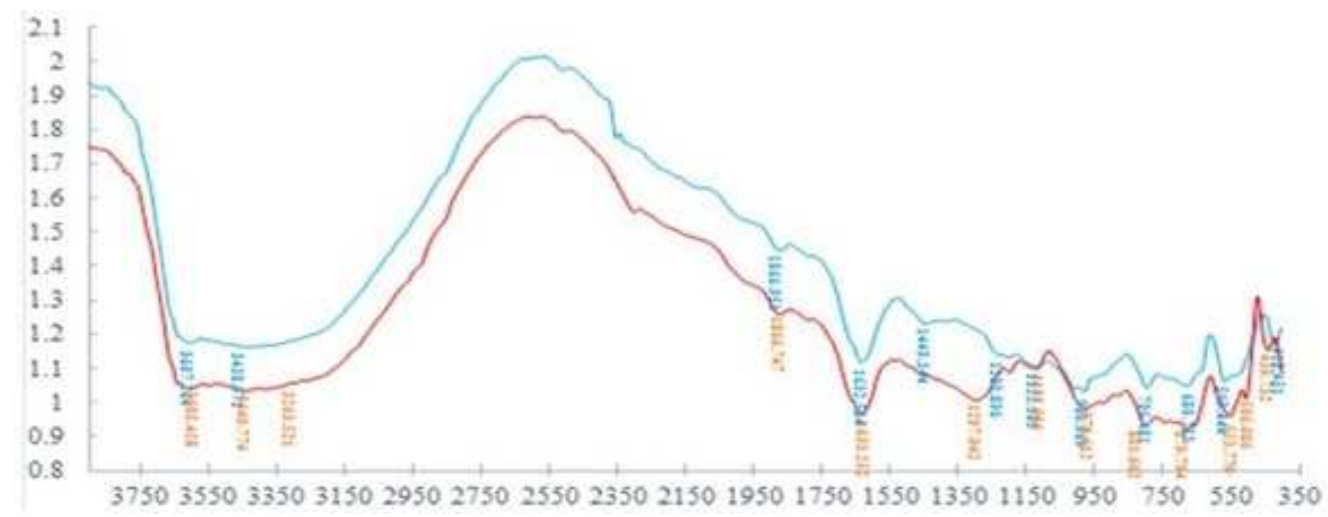

Figure 5. Spectra Infrared of activated zeolite sand before adsorption (blue curve) and after adsorption (red curve).

Figure 5 shows infrared spectra from activated zeolite sand samples after the adsorption process. Some of absorption peaks between total chromium ions and adsorbent appear not too strong because total chromium ions after precipitation process almost entirety has been deposited. The interaction of chromium metal ions with adsorbents occurred at $1600-1700 \mathrm{~cm}^{-}$ 1 .

Table 1. Pollutant content of wastewater before and after processing

\begin{tabular}{cccccc}
\hline No. & Parameter & $\begin{array}{c}\text { Max. } \\
\text { Concentration } \\
(\mathrm{mg} / \mathrm{l})\end{array}$ & $\begin{array}{c}\text { Concentration } \\
(\mathrm{mg} / \mathrm{l})\end{array}$ & $\begin{array}{c}\text { Concentration } \\
(\mathrm{mg} / \mathrm{l})\end{array}$ & $\begin{array}{c}\text { Elimination } \\
(\%)\end{array}$ \\
\hline 1. & BOD $_{5}$ & 50 & $3,920.440$ & 2.56 & 99.95 \\
2. & $\mathrm{COD}$ & 110 & $6,771.062$ & 4.35 & 99.93 \\
3. & $\mathrm{TSS}$ & 60 & 624.000 & 3.00 & 99.51 \\
4. & Total Cr & 0.6 & $2,646.500$ & 0.043 & 99.99 \\
5. & Sulfide (as S) & 0.8 & 0.2050 & 0.0249 & \\
6. & $\mathrm{pH}$ & $6.0-9.0$ & 4.6 & 8.6 & \\
\hline
\end{tabular}

${ }^{*}$ wastewater quality standards from Environment State Minister No. 51/MENLH/10/1995

${ }^{* *}$ initial tannery wastewater content

${ }^{* * *}$ final tannery wastewater content after process by precipitation and adsorption

In this study, elimination percent of adsorption was determined to observe the removal of total chromium ions after processed by precipitation with $\mathrm{Ca}(\mathrm{OH})_{2}$. Adsorption test was done by optimize the adsorbent weight i.e. $0.5 \mathrm{~g}, 1.5 \mathrm{~g}$, and $2.5 \mathrm{~g}$ in each $50 \mathrm{ml}$ of wastewater where this adsorption leaving the concentration of $0.098 \mathrm{mg} / 1,0.044 \mathrm{mg} / \mathrm{l}$ and $0.043 \mathrm{mg} / \mathrm{l}$ of total chromium ions, respectively. Whereas by optimize the contact time i.e. 30 minutes, 2 hours, 3.5 hours and 5.5 hours where this adsorption leaving the concentration of $0.048 \mathrm{mg} / 1,0.043$ $\mathrm{mg} / 1,0.044 \mathrm{mg} / \mathrm{l}$, and $0.042 \mathrm{mg} / \mathrm{l}$ of total chromium ions, respectively. Elimination of total $\mathrm{Cr}$ 
ions through the adsorption process gives almost the same results towards the variations of adsorbent weight and contact time. So that the optimum adsorption condition along as 30 minutes with an adsorbent weight $0.5 \mathrm{~g}$.

Before processing the initial measurements are taken to determine the level of pollutants in the tannery wastewater. Based on Table 1. it is shown that the parameters that exceed the quality standard are Biological Oxygen Demand $\left(\mathrm{BOD}_{5}\right)$ 3,920.44 mg/l, Chemical Oxygen Demand (COD) 6,771.062 mg/l, Total Suspended Solid (TSS) $624 \mathrm{mg} / \mathrm{l}$, total chromium ions $2,646.5 \mathrm{mg} / \mathrm{l}$ and $\mathrm{pH}$ 4.6. While sulfide that contained in the wastewater does not exceed the quality standard, which is $0.2050 \mathrm{mg} / \mathrm{l}$. $\mathrm{BOD}_{5}, \mathrm{COD}$ and TSS are parameters gives the amount of organic compound from the tannery wastewater. While the total chromium ions $(\mathrm{Cr})$ shows heavy metals contained from tannery wastewater as the hazardous and toxic of substances (B3). The measurement results of wastewater sample after treatment showed by reduction of total chromium to yield $0.043 \mathrm{mg} / 1, \mathrm{BOD}_{5}$ to yield $2.56 \mathrm{mg} / \mathrm{l}, \mathrm{COD}$ to yield $4.3504 \mathrm{mg} / \mathrm{l}, \mathrm{TSS}$ to yield $3.00 \mathrm{mg} / \mathrm{l}$, sulfide to yield $0.0249 \mathrm{mg} / \mathrm{l}$ and $\mathrm{pH}$ up to 8.6 .

The measurement results in Table 1. show that combination of precipitation and adsorption processes is an effective methods to reduce the pollutant parameters contained in the tannery wastewater. It is shown that all pollutant parameters produce the elimination level up to $99 \%$ and according to quality standard for tannery industry activities, so that the wastewater can be disposed directly into the effluent around human settlements.

\section{Conclusion}

Coagulant from chicken eggshell that calcined at $700^{\circ} \mathrm{C}$ gives the hydrated $\mathrm{CaO}$ that confirmed by XRD analysis, but $\mathrm{CaCO}_{3}$ residues was still present. Activated $\mathrm{BaCl}_{2}$ into zeolite sand that used as adsorbent has been occurred that confirmed by FTIR, which signed by the increase of peaks intensity at typical zeolite absorption area. Pollutant parameters such as total chromium ions, $\mathrm{BOD}_{5}, \mathrm{COD}$, TSS, Sulfide and $\mathrm{pH}$ have been decreased which it has been accordance with the quality standards from Decree of Environment State Minister with the efficiency level up to $99 \%$.

\section{Acknowledgment}

This publication was supported by Pusat Penelitian dan Penerbitan, Lembaga Penelitian dan Pengabdian Kepada Masyarakat (LP2M) UIN Sunan Gunung Djati Bandung.

\section{References}

[1] A. Asmadi, E. S, and W. Oktiawan, "Pengurangan chrom (Cr) dalam limbah cair industri kulit pada proses tannery menggunakan senyawa alkali $\mathrm{Ca}(\mathrm{OH}) 2, \mathrm{NaOH}$ dan NaHCO3 (studi kasus PT. Trimulyo kencana mas semarang)," J. Air Indones., vol. 5, no. 1, 2009.

[2] S. Setiadji, C. D. D. Sundari, M. Munir, and S. Fitriyah, "Synthesis of solid catalyst from egg shell waste and clay for biodiesel production," in Journal of Physics: 
Conference Series, 2018.

[3] K. Margeta, N. Zabukovec, M. Siljeg, and A. Farkas, "Natural Zeolites in Water Treatment - How Effective is Their Use," in Water Treatment, 2013.

[4] C. D. D. Sundari et al., "Synthesis of zeolite L using rice husk ash silica for adsorption of methylene blue: Kinetic and adsorption isotherm," in MATEC Web of Conferences, 2018.

[5] S. Setiadji et al., "Synthesis of zeolite ZSM-11 using bamboo leaf as silica source," IOP Conf. Ser. Mater. Sci. Eng., vol. 434, p. 012084, Dec. 2018.

[6] S. Setiadji et al., "The increased use value of bamboo leaves as silica source for ttype zeolite synthesis," in MATEC Web of Conferences, 2018.

[7] C. D. D. Sundari, S. Setiadji, A. L. Firmansyah, D. Abdurahman, and D. F. Nurbaeti, "Ag-ZSM-11 ZEOLITE SYNTHESIS USING SILICA FROM ELEPHANT GRASS FOR LED APPLICATION," Walisongo J. Chem., 2018.

[8] S. Setiadji, N. T. B, T. Sudiartati, E. Prabowo, and B. W. N, "Alternatif Pembuatan Biodiesel Melalui Transesterifikasi Minyak Castor (Ricinus communis) Menggunakan Katalis Campuran Cangkang Telur Ayam dan Kaolin,” J. Kim. Val., 2017.

[9] T. A. B. Prasetyo and B. Soegijono, "Characterization of sonicated natural zeolite/ferric chloride hexahydrate by infrared spectroscopy," J. Phys. Conf. Ser., vol. 985, p. 012022, Mar. 2018. 